I said nothing on the subject of compulsory Greels, but as my silence has been taken to imply complete assent to its abolition, let me say that while I have voted, and shall vote, against enforcing the study upon candidates for degrees in mathematics or natural science, I am convinced that the quality of any literary, historical, or philosophical study, whether in modern or ancient fields, is gravely injured wherever it is undertaken without a knowledge of Greek.

Manchester, November 20.

R. S. Conway.

\section{The Preservation of Natural Colour in Plants.}

IN NATURE of November 9 Dr. Rendle directs attention to a method of producing compounds of chlorophyll and copper similar in colour to that of the natural pigments of the leaf and of a comparatively stable nature. It may be worth while to point out that the chemical changes underlying the method are fairly well known, as a result of Willstätter's investigations of ehlorophyll and its derivatives. The knowledge derived from Willstätter's work forms a very profitable basis for an investigation of the problem of preserving the colour of herbarium specimens.

The chromogen complex of chlorophyll contains magnesium bound to nitrogen in a complex way. The chromogen group of chlorophyll $a$ may be represented by the formula, $\mathrm{C}_{32} \mathrm{H}_{30} \mathrm{ON}_{4} \mathrm{Mg}$. 'The magnesium is easily removed by the action of acids, and the derivatives thus obtained, phæophytin, phytochlorin, etc., containing the group $\mathrm{C}_{32} \mathrm{H}_{32} \mathrm{ON}_{4}$, have optical properties different from those of chlorophyll; in solutions they are of a yellowish-olive green colour, and they exhibit characteristic absorption spectra.

It is possible in many cases to introduce a metal into these magnesium-free derivatives whereby compounds with optical properties similar to those of chlorophyll are produced. A full discussion of the various methods for introducing the different metals is out of place here, but it may be pointed out that magnesium can be reintroduced into the chlorophyll molecule by treatment with methyl magnesium iodide. Some metals are very easily introduced-e.g. copper, zinc, and iron-by treating the magnesium-free derivative with the metallic acetates in acetic acid or alcohol; zinc acetate even acts in cold solution.

It is a remarkable fact that some of these metal compounds are more stable-for example, in relation to acids-than the original magnesium complex. It is possible to arrange the metals in a series according to the stability of the compound; the extremes of this series are potassium (very unstable) and copper (very stable). Magnesium occupies an intermediate position.

The procedure in the treatment of a specimen is thus the following :-

(I) The Magnesium is removed from the Chlorophyll.-This can easily be done in the case of plants with an acid cell-sap (e.g. Oxalis acetosella) by dipping them into boiling water. In other cases the tissues can be made permeable by treatment with alcohol or acetone (in such a concentration that chlorophyll is insoluble, i.e. 1o-6o per cent.). Subsequent treatment with dilute acid removes the magnesium.

(2) The Metal is introduced.- It must be remembered that zinc, although a little less stable than copper, can be introduced without heating, and thus without the risk of injuring the specimen. The shade of colour obtained varies with the different metals.

Investigations on these two points will no doubt add to our knowledge. of the most suitable methods of preserving the colours of museum specimens of plants.

INGVAR JÖRGENSEN.

Department of Plant Physiology and Pathology,

Imperial College of Science and Technology, London, November I4.

\section{Artillery and Rainfall.}

THE following quotation may help to settle the question as to the effect of artillery on the rainfall, at any rate so far as the present generation of your readers is concerned.

It is taken from a translation of "Plutarch's Lives," by John and William Langhorne, and occurs in the life of "Caius Marius," where Plutarch comments on a battle fought against the "Teutones" in ro2 B.C.

"It is observed, indeed, that extraordinary rains generally fall after great battles; whether it be that some deity chooses to wash and purify the earth with water from above, or whether the blood and corruption, by the moist and heavy vapours they emit, thicken the air, which is liable to be altered by the smallest cause."

Now, since the battles and rainfall referred to occurted some $5_{500}$ years before artillery was invented, it is clear that artillery cannot be the cause of the rainfall. MORItURus.

\section{GOVERNMENT CONTROL OF FOOD SUPPLIES.}

WHATEVER difference of opinion may exist in regard to the stimulus which has moved the Government to take control of our food supplies, all are agreed that it has not come about a moment too soon, and most will admit that we should now be much better off had it been taken in hand more than a year ago.

The provisions outlined will empower the Food Controller to take measures both preventive and regulatory; the former to prevent waste, the improper use of food, such as giving to animals food that ought to be reserved for human beings, and market manipulation, cornering, or holding up of food supplies. The regulatory measures apply to the production of flour from grain, the sale and distribution of articles of food, and the fixation of prices.

If properly and intelligently applied, the scheme ought to work well. There can be no doubt that a great deal of food is still wasted, not alone by sections of the population who are earning more money than they have ever handled before, but also by public institutions; and many still believe in the catering for the Army, although this last has been improved. Nothing short, however, of some measure equivalent to "food tickets" will prevent over-consumption and waste on the part of those who, owing to the war, are better off than in normal times. But by a strict system of inspection it ought to be possible to reduce or abolish waste in public institutions and in the Services.

It is, perhaps, in respect to the application of the regulatory provisions that the public may harbour some misgivings, and particularly in respect to the manufacture of wheat-flour-a subject which is dealt with elsewhere in this issue.

The control of sale and distribution is certain to prove a difficult undertaking, but with suitable organisation it can in time be satisfactorily attained. The most delicate problem of all is, however, the fixation of prices, and here expert knowledge of food values will be indispensable if approximately the same amount of nourishment

NO. 2456 , VOL. 98$]$ 
is to be obtained in different foods for a given sum of money. This applies in particular to staple articles of diet, such even as bread and potatoes. Thus, for instance, with bread at $3 d$. per 1b., potatoes to yield an equal amount of nourishment should not exceed is. per stone.

But Government measures cannot stop with the mere regulation of food supplies. Powers must be taken to compel a greater production of home food and to ensure a larger acreage of wheat. Objection may be raised to the shortage of labour, but what adequate effort has been made to organise and instruct women to take part in agricultural labour, or to feed them properly when so employed? What effort has been made to increase tillage in Ireland, where the Military Service Acts do not apply? Lastly, why should prisoners of war not be utilised to the fullest degree possible in raising the home production of food? No considerations, political or otherwise, should be allowed to stand in the way of carrying any or all of these measures into effect without further delay.

\section{STANDARD BREAD}

THE decision of the Government, which appears 1 likely to result in the general consumption of "standard bread," will no doubt be received with varied feelings by various sections of the community. In view of the certainty that such differences of opinion are likely to arise, the following brief sketch of the facts of the case so far as they are known may be of general interest.

Under normal conditions at the present time the average practice of roller milling results in the recovery from cleaned wheat of rather more than 70 per cent. of its weight of flour, the remaining 28 or 29 per cent. of the wheat, consisting of various grades of "offals," being sold for feeding stock.

The changes announced last week would make it compulsory to recover 80 per cent. of flour from wheat, which would increase the amount of flour by about $8 \frac{1}{2}$ per cent. and decrease the amount of offals for stock-feeding by a like proportion, the percentage in both cases being. calculated on the amount of cleaned wheat available for milling. ${ }^{1}$

On the basis of the amount of flour produced in the United Kingdom for home consumption in the years immediately before the war, the change announced would increase the amount of flour available for bread-making by very nearly 600,000 tons, which would provide an extra $2-1 \mathrm{~b}$. loaf for every inhabitant of the United Kingdom every three weeks, or seventeen extra $2-1 \mathrm{~b}$. loaves per head of the population per year. This is by no means a negligible increase in the bread supply, and it is doubtless considerations of this kind that have induced the Government to take action.

If, however, we examine the result rather more closely, we find that the increase in the nation's

1 The values here given require modification in the light of the Order just made by the Board of Trade (see p. 232).

NO. 2456, VOL. 98] food supply may not be so great as the above figures indicate. In spite of repeated statements to the contrary, bread made from 80 per cent. flour is not so nutritious, weight for weight, as bread made from 70 per cent. flour-at any rate, for the supply of protein and energy for the general population. Although 80 per cent. bread contains on the average rather more protein than 70 per cent. bread, the digestibility of the protein in the former is rather lower, so that the actual weight of protein digested by the average individual from I 1 b. of 80 per cent. bread is rather less than the amount digested from I $\mathrm{lb}$. of 70 per cent. bread. Again, the energy value of 80 per cent. bread is rather lower than that of 70 per cent. bread. Still one more correction must be made in order to arrive at the actual increase in the national food supply which will result from the general adoption of a milling standard of 80 per cent. It is pointed out above that the recovery of 80 per cent. of flour from cleaned wheat entails a decrease in the supply of the finer wheat offals for stockfeeding to the extent of about 600,000 tons. These finer offals are largely used for feeding pigs. Their transference to human consumption would therefore decrease the production of pork and bacon, and this must be allowed for in estimating the total effect of the proposed alterations in milling. After applying all these corrections it appears that the general adoption of an 80 per cent. standard would undoubtedly give a substantial increase in the amount of digestible food for the supply of protein and energy for the population of the United Kingdom.

The possibility that the food value of bread would be substantially increased by the adoption of the 80 per cent. standard, because the content of the mysterious constituents known as vitamines would be increased by the inclusion of a greater proportion of the germ and of the outer layers of the grain, is perhaps scarcely worth discussing in this connection. Such constituents are sup. plied by other items comprised in an ordinary mixed diet, so that the vitamine content of bread can have little practical significance except in the very few cases where bread forms the whole, or very nearly the whole, of the diet.

The price of wheat offals for feeding stock is now so high that the adoption of the 80 per cent. standard cannot be expected to make any considerable reduction in the price of bread. Even the compulsory admixture of a considerable pro. portion of other cereals, such as maize, oats, or barley, with wheat for bread-making would not greatly cheapen the loaf, because these cereals are not very much cheaper than wheat. The important point in raising the milling standard and in including other cereals among the breadstuffs is that it would widen the sources from which the national food supply is derived - a most desirable end under existing conditions. To summarise, the result of a compulsory 80 per cent. standard would be neither better bread nor cheaper bread, but more bread. 